\title{
Student Management Model in The Character Development: A Case Study in Laboratory School
}

\author{
Uswadin $^{1}$, Bedjo Sujanto ${ }^{2}$, Muchlis Rantoni Luddin ${ }^{3}$ \\ \{dinuswa15@gmail.com ${ }^{1}$, bejosujanto@unj.ac.id $\left.{ }^{2}\right\}$ \\ Universitas Negeri Jakarta, Indonesia ${ }^{123}$
}

\begin{abstract}
Abstact. The challenges of students' negative behavior are one of the biggest problems faced by the education system in Indonesia. Therefore, character development has become a key focus in current curricula. The laboratory school is a model integrated with the pedagogical university. The objective of this study is to explore students management model in the area of Character Development. The study involves the principal, teachers, parents, and students as participants. The research used a methodology with multiple data collection as a case study. The data collected reveals that the school has implemented several strategies to enhance student management in the process of students admission and extracurricular activities. The school employed various strategies of students leadership, involvement and making character education an integral part of the education process. Character development is gradually being implemented by collaboration and shared the responsibility of the principal, parents, and community. The laboratory school has developed a comprehensive approach of emotional, intellectual, and moral development for the students.
\end{abstract}

\section{Introduction}

Junior High School (SMP) is a primary education institution currently serving as an institute for continuation in Elementary School. In this citadel, there is room for the development of students potential in all fields through curricular, intracurricular and extracurricular activities. Education in junior high school in the future is targeted towards achieving National Education Goals. Republic of Indonesia Law Number: 20 the year of 2003 concerning National Education System, Chapter II Article 3 states that: "National Education is vested with the responsibility of developing potentials. They help to form classic national character and civilization to educate the nation's life through the development of students potential to become human beings who believe and fear God Almighty, have a noble character, good health, knowledge, capacity, creativity, and independence".

From the above, the school is expected to successfully manage all these activities so that it can achieve the set goals of national education. The ability of schools to manage these activities in addition to providing complete and good academic services to students will make the nation stand out regarding quality education.

Character development is successfully built by schools with good planning and implementation accompanied by routine evaluation of each aspect. The decline of good character in the younger generation is a potential problem for schools in particular and society in general. Hence, the school must seek to implement character education in the development 
of participants in all school activities, especially in the student management. Character education will enable students to build a strong identity and an entire personality.

Education management as a branch of management science is very vital in the implementation of education for maximum productivity. Good management will enhance good education, and conversely, poor management of education leads to poor education. Therefore, proper education management will positively affect the quality of life of a society and nation. According to Mulyasa, the development of students through proper structuring and regulation of school activities will help students when they get out of school [1].

Syarif Hidayat explained that student management involves the recording of students activities from the admission process until the student graduation or exit. According to Eka, student management refers to jobs or activities from the admission process to when students leave school on the basis that they have finished attending the school [1].

Thomas Lickona stated that character is "A reliable inner disposition to respond to situations in a morally good way." Furthermore, Lickona added, "Characterization has three interrelated parts: moral knowing, moral feeling, and moral behavior." According to Lickona, noble character (good character) has to do with knowledge of goodness, raising commitment (intention) towards goodness, and finally doing good. In other words, the character refers to a set of knowledge (cognitive), attitudes (attitudes), and motivations (motivations), as well as behaviors (behaviors) and skills (skills). Lickona mentions eleven principles that are effective in instilling character values. They are as follows: (1) promoting priority or core values and supporting the implementation of these values as a basis for the good character, (2) defining characters comprehensively covering thoughts, feelings, and behavior. (3) using a comprehensive, in-depth, and proactive approach to character implementation and development, (4) creating a caring school community, (5) providing opportunities for students to take moral actions, (6) compiling curriculum that is meaningful and respectful to students, developing their character, and helping them to achieve success. (7) strives to maintain students' self-motivation, (8) involving all school members into a learning and moral communities jointly responsible for character implementation and development, and striving to adhere to high values at the same standards that will set an example for students, (9) maintaining moral leadership and supporting character education initiatives, (10) involve family members and the community as partners in character building efforts, and (11) emphasize school character and placing school components (principals, teachers, and employees) to function as teachers and role models for character building, to arrive at students in realizing good character. [2] In essence, character education in schools begins with formulating moral values that will enhance the students character, socialize it in the school system, apply it to the school curriculum and make habituation involving all students, parents and school citizens so that it continues to be a school culture continuously and in the formation of good character.

School Laboratory has a significant role to play in the application and development of student management. Its success in successfully engaging in student development is a model for other schools. SMP Labschool Jakarta is one of the laboratory schools under the auspices of UNJ, and it has effectively applied student management to a great extent. The researcher intends to discover more about student management activities in supporting character education in schools. Can good student management enhance the implementation of character education at school? It is a known fact that the government is now re-launching the strengthening of character education in schools. This is vital because there are indications of negative characters in students caused by advances in science and technology, such as the massive and unavoidable gadgets and internet influences. some students engage in disrespectful actions, and a decreased sense of nationalism is perceived among many students. 


\section{Methodology}

This research uses a qualitative approach with a case study model, and data collection was carried out using interviews with school components, observation, and documentation studies. To add data merging, focus group discussions were also conducted. The study involved principals, vice principals, teachers, school committees, alumni and parents of students. The Research was performed within a time range of fifteen months from August 2017 to November $2018^{1} \cdot[3]$

\section{Result And Discussion}

From the results, this school has successfully implemented student management, and this is indicated by the well-planned and organized online new students registration. Therefore citizens from any location can register at this school. Registration of new students with the online system is one of the secrets to the success of the school in student management [4] Furthermore, this school also excellently perform student orientation activities, and this is demonstrated through various activities through which they present competent speakers. The school also has diverse student programs, extracurricular activities, and leadership as well as disciplinary training activities in collaboration with the military. Activities that enhances student management and character education in schools are properly conducted. This is because they get support from the students and parents. This is in line with what Lickona has conveyed in 11 principles of character development.

character education should bring learners to cognitive value recognition, affective value appreciation, and finally to actual values. Character education in junior high schools needs to be studied to bring alternative solutions and development. [5]

Character education can be integrated into each subject. Learning materials relating to norms or values in each subject needs to be developed, made explicit, and related to the context of everyday life. Therefore, learning character values is not only at the cognitive level, but it involves internalization and real-life practices by the students in their everyday lives.

Student development activities undertaken by various schools are one of the potential media for character education and enhancement of students academic quality. The character development of students in some schools is comprehensively carried out continuously. It is also well integrated synergistically. The character development of students in schools is carried out comprehensively and continuously, integrated and synergistically[1]. Student coaching activities are extracurricular activities that help in the development of students according to their needs, potential, talents, and interests. Through these activities, the ability and sense of social responsibility of the students are enhanced. It also improves participants potential.

Character education in schools is greatly influenced by school management. Management is involved in how character education is planned, implemented, and controlled. Proper Management among others includes the values that need to be instilled, the content of the curriculum, learning, assessment, educators and education staff, and other related components. The principle of developing national culture and character in the 2013 curriculum is not included as a subject but is integrated into various subjects by self-development and school culture. 
Eighteen values in character education according to the department of education and culture includes Religious, Honest, Tolerance, Discipline, Hard Work, Creative, Independent, Democratic, Curiosity, National Spirit, Love of the Motherland, Respect for Achievement, Friendly / Communicative, Love Peace, Love to Read, Care for the Environment, Care for Social, Responsibility. The Ministry of Education and Culture under the leadership of Mr. Muhadjir Effendy in 2016 launched the Character Education Strengthening Activity for Elementary and Middle School.

Five main values of interrelated characters formed a value network that needs to be developed as a priority for the Strengthening Character Education Movement. The five main values of the national character in question composites of 1 . Religious, 2. Nationalist, 3. Independent, 4. Mutual Cooperation and 5. Integrity. [5].The implementation of the five main character values in the school enables the students to build a better character by cooperation with parents. [6]

The development of students at SMP Labschool Jakarta was successfully conducted through integrated activities in academic and non-academic fields by the motto of the Creative, Achieving and Character. The school formulated various processes in such a way that it has improved students' activities to become fun, challenging and meaningful.

Proper students Guidance begins with Student Orientation Period to Extra-curricular Expo, SALAM Culture, Dhuhr Jamaah Prayers, Culture, Ashar Jamaah Prayer, Tadarus, Scout activities, National Olympiad Science and Art Team Development, Islamic Boarding Schools, Retreats (Christian), Tirta Nyadnya (Hinduism), Field Study, Study and Appreciation of Indonesian Student Leadership (SAKSI), Social Services, Student Leadership Basic Training (LDKS), Student Management Skills Exercises (LKMS), Writing Work, Lab scared, Industry Visit (invited), Crossroad Running, Student Exchange, Drama Performance, Focus of National Exams, Achievement Motivation Training, Farewell, and lastly Graduation.

The date vividly demonstrates that the laboratory school has successfully implemented different strategies to manage students from the process of students' admission, teaching and learning, tests and evaluations, and many extracurricular activities. The school has integrated strategies of students' leadership, involvement and making character education is a vital part of the education process. Character development has been successfully implemented by collaboration and shared the responsibility of the principal, teachers, students, parents, and community. The school faced the challenges of time management, students' achievement, and engagement; the laboratory school has developed a comprehensive approach to emotional, intellectual, and moral development for the students.

\section{Conclusion}

The results of the study from SMP Labschool Jakarta can be explained by students entering school to leaving school. From a general point of view, character education implementation in schools is successful because of the readiness on the part of the management and schools cooperation with all parties. Character education when properly implemented and supported by good student management will have a good and positive impact on the school. SMP Labschool Jakarta consistently engaged in students management and this has given the school a good name. The School with the motto of Creative, Achievement and Character has lived up to the expectations of their motto. This is displayed by the emergence of creative and accomplished 
children with good characters from this school. Indeed, the motto is a prayer and encouragement to achieve what is dreamed and written.

Student management that properly implements students management has high tendencies to produce students with exceptional self-confidence and good fighting ability. Student management can simultaneously support the implementation of character education in schools. The parents gain satisfaction because their children are properly built with good character, this will, in turn, enable them to support school programs. With good support from school members and parents, the school will easily achieve the desired goals and objectives. This has been demonstrated by SMP Labschool Jakarta. Thus, school management is one of the active media for character education development in schools.

\section{References}

[1] CEP. (2010). 11 Principles of Effective Character Education: A Framework for School Success, 28. https://doi.org/10.1080/0305724960250110

[2] Efektif, S. (2013). Universitas negeri gorontalo november 2013 1, (November), 1-232.

[3] Husen, A. (2017). Pengembangan Karakter Siswa pada SMP Labschool Jakarta Yayasan Pembina Universitas Negeri Jakarta.

[4] Kemdikbud. (2016). Kajian dan Pedoman Penguatan Pendidikan Karakter (PPK), 1-90. https://doi.org/10.1360/zd-2013-43-6-1064

[5] Kemendiknas_c. (2010). Panduan pendidikan karakter di sekolah menengah pertama, 2010.

[6] Mulyasa, E. (2003). Manajemen Berbasis Sekolah.

[7]Muttaqin, Muhammad Fauzan. Raharjo, T. J. M. (2018). file://C:/Users/User/Documents/Disertasi 2017/View of The Implementation Main Values of Character Education Reinforcement in Elementary School.pdf. Journal of Primary Education UNNES, 103-112.

[8] Student management model in the character development. (2018). Uswadin. (2019, January 7). Student Management Model in The Character Development: A Case Study in Laboratory School. Retrieved from Osf.Io/3rcx7. 